\title{
Phylogeny of Bacteria from Steelmaking Wastes and Their Acidic Enrichment Cultures
}

\author{
Mariana P. Reis ${ }^{1}$, Flaviane A. Pinheiro ${ }^{1}$, Patrícia S. Costa ${ }^{1}$, Ana Paula C. Salgado', \\ Paulo S. Assis ${ }^{2}$, Edmar Chartone-Souza ${ }^{1}$, Andréa M. A. Nascimento ${ }^{{ }^{*}}$ \\ ${ }^{1}$ Departamento de Biologia Geral, Instituto de Ciências Biológicas, Universidade Federal de Minas Gerais, \\ Belo Horizonte, Brazil \\ ${ }^{2}$ Departamento de Engenharia Metalúrgica e de Materiais, Escola de Minas, Universidade Federal de Ouro \\ Preto, Ouro Preto, Brazil \\ Email: ${ }^{*}$ amaral@icb.ufmg.br
}

Received 8 July 2014; revised 3 August 2014; accepted 5 September 2014

Copyright (C) 2014 by authors and Scientific Research Publishing Inc.

This work is licensed under the Creative Commons Attribution International License (CC BY). http://creativecommons.org/licenses/by/4.0/

c) (i) Open Access

\begin{abstract}
Currently, millions of tons of steel are produced worldwide. This has become a serious economic and environmental challenge because the ores used for steel production are nonrenewable resources and the production generates huge amount of waste. In this study, we identified and investigated the ability of bacteria from steelmaking waste with low and high zinc concentration to promote leaching of zinc, when enriched by acidic (pH 2) culture conditions. The bioleaching assays indicated removal of $\mathrm{Zn}$, as in chemical leaching. Bacterial communities from crude and enrichment culture wastes were characterized by the 16S rRNA gene. Phylogenetic analysis of the generated clone libraries revealed predominance of Proteobacteria and Firmicutes. The Actinobacteria, Bacteroidetes, Cyanobacteria, and Deinococcus-Thermus phyla were also encountered. The clones were most closely related to cultivable heterotrophic bacteria. Different genera were identified including iron redox cycling and leaching bacteria such as Chromobacterium, Aeromonas, Escherichia, Bacillus, and Ochrobactrum. These data add significant new information on bacteria which survive in extremely acidic conditions. They are distantly related to typical acidophiles responsible for the leaching process, which makes them good candidates for future studies on metal bioleaching.
\end{abstract}

\section{Keywords}

Bacteria, 16S rRNA, Diversity, Zinc, Steelmaking Wastes

\footnotetext{
${ }^{*}$ Corresponding author.
}

How to cite this paper: Reis, M.P., Pinheiro, F.A., Costa, P.S., Salgado, A.P.C., Assis, P.S., Chartone-Souza, E. and Nascimento, A.M.A. (2014) Phylogeny of Bacteria from Steelmaking Wastes and Their Acidic Enrichment Cultures. Advances in Microbiology, 4, 816-828. http://dx.doi.org/10.4236/aim.2014.412090 


\section{Introduction}

Steelmaking activities have been particularly intensive during the 20th and 21st centuries, resulting in the generation of huge amounts of waste (approximately $700 \mathrm{~kg}$ of waste per ton of steel produced) including the presence of metals such $\mathrm{Zn}, \mathrm{Cu}$, and $\mathrm{Cr}$ [1]. Indeed, most of the waste is being left without proper management all over the world and without any management whatsoever in Brazil and perhaps in other countries as well. The release of these wastes to the environment leads to contamination and consequent human exposure to the metals present in these rejects. The World Steel Association reported an increase of 6.8\% in steel production in 2011 resulting in 1.527 billion tons, of which Brazil contributed about 35.2 million tons (www.iabr.com.br). Thus the waste generated by this industry can no longer be ignored. First steps towards solutions for its management would be the search for suitable technologies to enable the removal of metals from these wastes.

Bioleaching of metals has gained increased attention since it is innovative, environmentally friendly, and economical [2]. Indeed, bioleaching has been considered as an alternative strategy for the extraction of metals from complex ores or wastes, which may reduce costs up to $80 \%$ when compared with traditional chemical techniques [3]. This biotechnological process is based on the ability of microorganisms to oxidize ferrous iron and/or reduce sulfur compounds [4]. The predominant metal-sulfide-dissolving bacteria that have been extensively used for the bioleaching of sulfide minerals with commercial interest are extremely acidophilic [5] [6] although heterotrophic bacteria can also contribute to metal leaching [7].

The process of production of steel involves many stages, from reduction of iron ore at temperatures reaching $2400^{\circ} \mathrm{C}$ (in a blast furnace) to metal plating, which uses a large amount of $\mathrm{Zn}$ to protect the steel from corrosion. Overall, the wastes contain tramp metals such as $\mathrm{Zn}, \mathrm{Cu}$, and $\mathrm{Cr}$ preventing their recycling for steel production due to possible damage to industry furnaces by these metals. Nevertheless, $\mathrm{Zn}$ is economically important due to its anti-corrosive and pharmaceutical properties. In this study, we identified and investigated the ability of heterotrophic bacteria from steelmaking wastes to survive in acidic conditions and to promote leaching of zinc.

\section{Materials and Methods}

\subsection{Sampling and Chemical Composition of the Wastes}

Steelmaking waste samples were collected at Usiminas (Ipatinga, Minas Gerais state, Brazil) using sterilized bottles. The wastes studied were crude thin sludge waste (TS), constituted by fine solid particles resulting from the Linz-Donawitz converter (or BOF), and crude sludge from treatment of electroplating effluent waste (STEE), both of which were released into the environment three days before sampling. X-ray fluorescence spectrometer (PW 2510 Sample Changer, Philips) analysis of the wastes revealed 1.9\% and $29.8 \% \mathrm{Zn}, 57 \%$ and 5.5\% Fe, and $11 \%$ and $40 \% \mathrm{Ca}$ in the TS and STEE wastes, respectively. The efficiency in Zn extraction was compared using an unpaired t-test, performed by PAST data analysis package. The level of significance was considered at $\mathrm{p} \leq$ 0.05 .

\subsection{Acidic Enrichment Culture}

Acidic enrichment cultures were established by blending $10 \mathrm{~g}$ of the separate TS and STEE wastes into $100 \mathrm{~mL}$ of Leathen medium [8], and were respectively named TSC and STEEC. Prior to the bioleaching experiments the $\mathrm{pH}$ values of the crude STEE and TS wastes were 7 and 5, respectively. To prepare primary enrichment of heterotrophic bacteria, crude TS and STEE wastes were added to flasks and then treated with $\mathrm{H}_{2} \mathrm{SO}_{4}$ to reduce the $\mathrm{pH}$ value to 2 and thereby provide adequately acidic conditions for bacterial growth. The flasks were then incubated at $30^{\circ} \mathrm{C}$ with agitation $(200 \mathrm{rpm})$ for 40 days. The $\mathrm{pH}$ was monitored daily and adjusted with $\mathrm{H}_{2} \mathrm{SO}_{4}$ as needed. At the end of this period, we obtained the primary bacterial enrichment samples from each type of waste, TSC and STEEC.

\subsection{Bioleaching Assay}

Bioleaching assays were performed in $500 \mathrm{~mL}$ Erlenmeyer flasks. Each flask contained $180 \mathrm{~mL}$ of Leathen medium, $10 \mathrm{~g}$ of autoclaved waste (5\% w/v), and $20 \mathrm{~mL}$ of TSC or STEEC (10\% v/v). The flasks were incubated at $30^{\circ} \mathrm{C}$ with agitation (200 rpm) for 30 days. The $\mathrm{pH}$ value in the leaching solution was kept constant (pH 2) throughout the leaching process by adding $\mathrm{H}_{2} \mathrm{SO}_{4}$ as need. After this period, the wastes were filtered, dried at 
$110^{\circ} \mathrm{C}$ for one hour, and the concentration of $\mathrm{Zn}$ was measured by X-ray fluorescence spectrometer. These samples were henceforth called TSB and STEEB depending on the origin of inoculum used to start the bioleaching assay.

Non-inoculated controls consisted of autoclaved crude TS and STEE acidified and subjected to the same conditions as the TSC and STEEC tests. However, the $\mathrm{pH}$ of control flasks was monitored daily and continuously adjusted to $\mathrm{pH} 2$ with $\mathrm{H}_{2} \mathrm{SO}_{4}$.

\subsection{DNA Extraction and PCR Amplification of 16 S rRNA Gene}

Total DNA from waste (crude TS and STEE) and primary enrichment (STEEC and TSC) samples were isolated by using a $\mathrm{Max}^{\mathrm{TM}}$ Power DNA Isolation Kit for soil and water (MO Bio Laboratories) according to the manufacturer's instructions. The DNA samples were stored at $-20^{\circ} \mathrm{C}$ until further processing.

The bacterial 16S rRNA gene fragment was amplified using touchdown PCR according to Freitas et al. [1], using the primer set 8f (5'AGAGTTTGATCMTGGCTCAG 3') and 907r (5'ACGGHTACCTTGTTACGACTT 3') [9].

\subsection{Cloning, Sequencing, and Clone Library Analysis}

Bacterial 16S rRNA gene fragments were gel-purified using the Silica Bead DNA Gel Extraction Kit (Fermentas, Canada), cloned into the vector pJET1.2/blunt (Fermentas, Canada) according to the manufacturer's instructions, and transformed into electrocompetent Escherichia coli XL1Blue. Partial 16S rRNA gene sequences were obtained using the pJET1.2 forward and reverse primers and a Mega BACE 1000 capillary sequencer (GE Healthcare, United Kingdom) according to the manufacturer's instructions. Further, the sequences were checked for quality, aligned, and edited to produce a consensus using the programs Phred v. 0.020425 [10], Phrap v. 0.990319 [11], and Consed 12.0 [12]. Chimeras were checked and omitted using Bellerophon software

(http://comp-bio.anu.edu.au/bellerophon/bellerophon.pl). Closely related sequences from Greengenes [13] were identified by blast tool using the Silva database. Phylogenetic relationships were inferred with ARB software [14]. The operational taxonomic units (OTUs) were set at 97\% level identity using the DOTUR software [15]. Library coverage was calculated using the equation $C=1-(n / N)$, where $n$ denotes the number of unique OTUs and $N$ is the number of sequences analyzed in the library [16]. The diversity of the OTUs was further examined using DOTUR software, LIBSHUFF statistics [17], and rarefaction analysis. A comparative analysis was performed in order to detect OTU sequences shared among the four libraries. This analysis was performed using the DOTUR software [15] to detect sequence similarity at 97\% level. The partial 16S rRNA gene sequences generated were deposited in the GenBank database under accession numbers KC164772-KC164863.

\section{Results}

\subsection{Bioleaching of Zinc by Bacteria from Steelmaking Waste}

In an attempt to extract Zn from the steelmaking wastes (STEE and TS) bioleaching assays were performed using bacteria from enrichment cultures of these wastes (STEEC and TSC). During bioleaching experiments the $\mathrm{pH}$ initially increased over the first seven days, being thus adjusted to $\mathrm{pH} 2$ as indicated in the Materials and Methods section. After this time, acidity remained stable in the test flasks but not in the control flasks, which needed $\mathrm{pH}$ adjustments throughout the study period. Bioleaching efficiency was calculated by difference between the Zn contents in the crude TS and STEE samples and TSB and STEEB residues determined by X-ray fluorescence analysis. The data obtained revealed that STEEB (76\%) and TSB (53\%) presented efficiency in Zn extraction. Chemical leaching of $\mathrm{Zn}$ in the control flasks reached $82 \%$ and $47 \%$ for the STEE and TS wastes, respectively. Both leaching assays were equally efficient to remove $\mathrm{Zn}(\mathrm{p}=0.02)$.

\subsection{Phylogenetic Affiliation}

To reveal the phylogenetic identity of the bacteria, 16S rRNA gene clone libraries were constructed from crude TS and STEE wastes and from the TSC and STEEC enrichments. A total of 324 partial 16S rRNA gene sequences were obtained upon removal of chimeric sequences. These sequences were clustered into 94 OTUs spanning six bacterial phyla, mostly represented by cultivated heterotrophic bacteria. Clone libraries coverage 
accounted for $>67 \%$ of the bacterial diversity. Rarefaction curves generated from our data did not reach an asymptote, indicating an amount of undetected diversity, especially for the STEEC (Figure 1). The phylogenetic distributions of the OTUs and the resulting phylogenetic trees are shown in Figure 2 and online Resources 1-4, respectively.

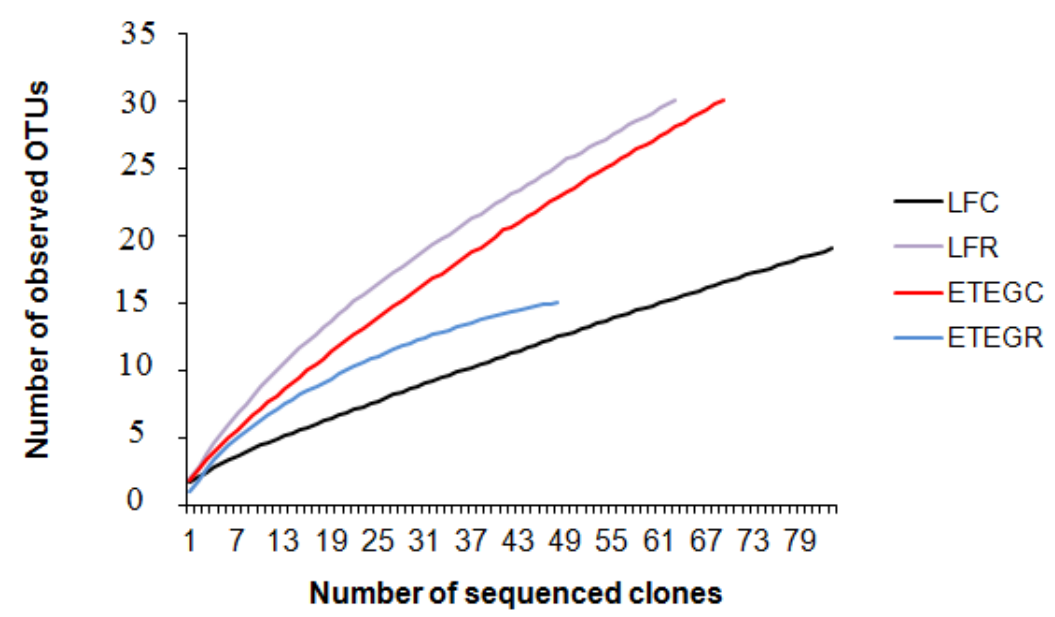

Figure 1. Rarefaction analysis of bacterial 16S rRNA gene sequences from crude sludge from treatment of electroplating effluent (STEE), enrichment culture from treatment of electroplating effluent (STEEC), crude thin sludge (TS), and enrichment culture from thin sludge (TSC). The total number of sequenced clones is plotted against the number of OTUs observed in the same library. The OTUs were defined at the $\geq 97 \%$ identity level (species level).

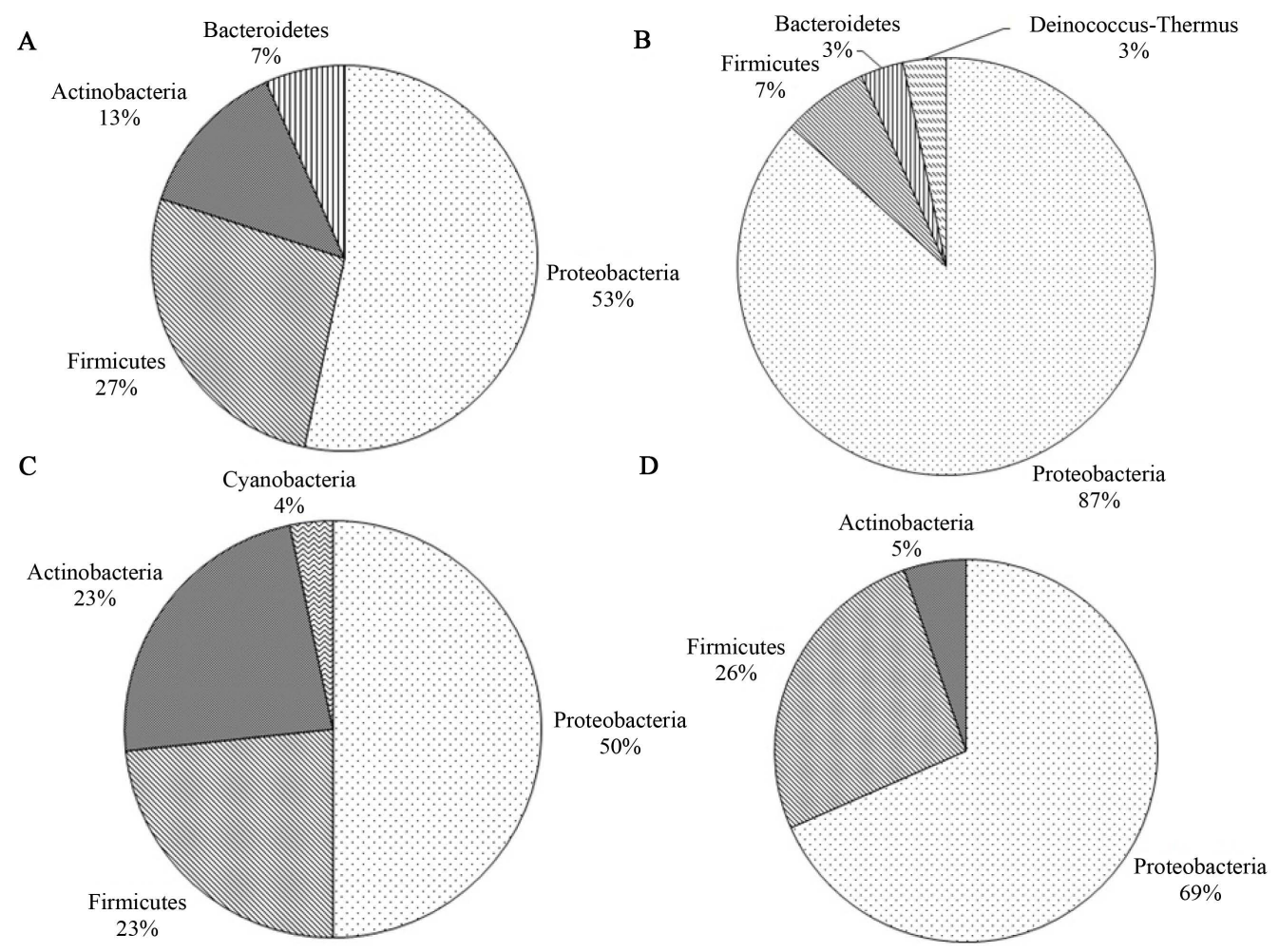

Figure 2. Phylogenetic ARB affiliation of bacterial 16S rRNA genes. The numbers indicate the percentage representative of each phylum in the library. (A) crude sludge from treatment of electroplating effluent (STEE); (B) enrichment culture from treatment of electroplating effluent (STEEC); (C) crude thin sludge (TS); and (D) enrichment culture from thin sludge (TSC). 


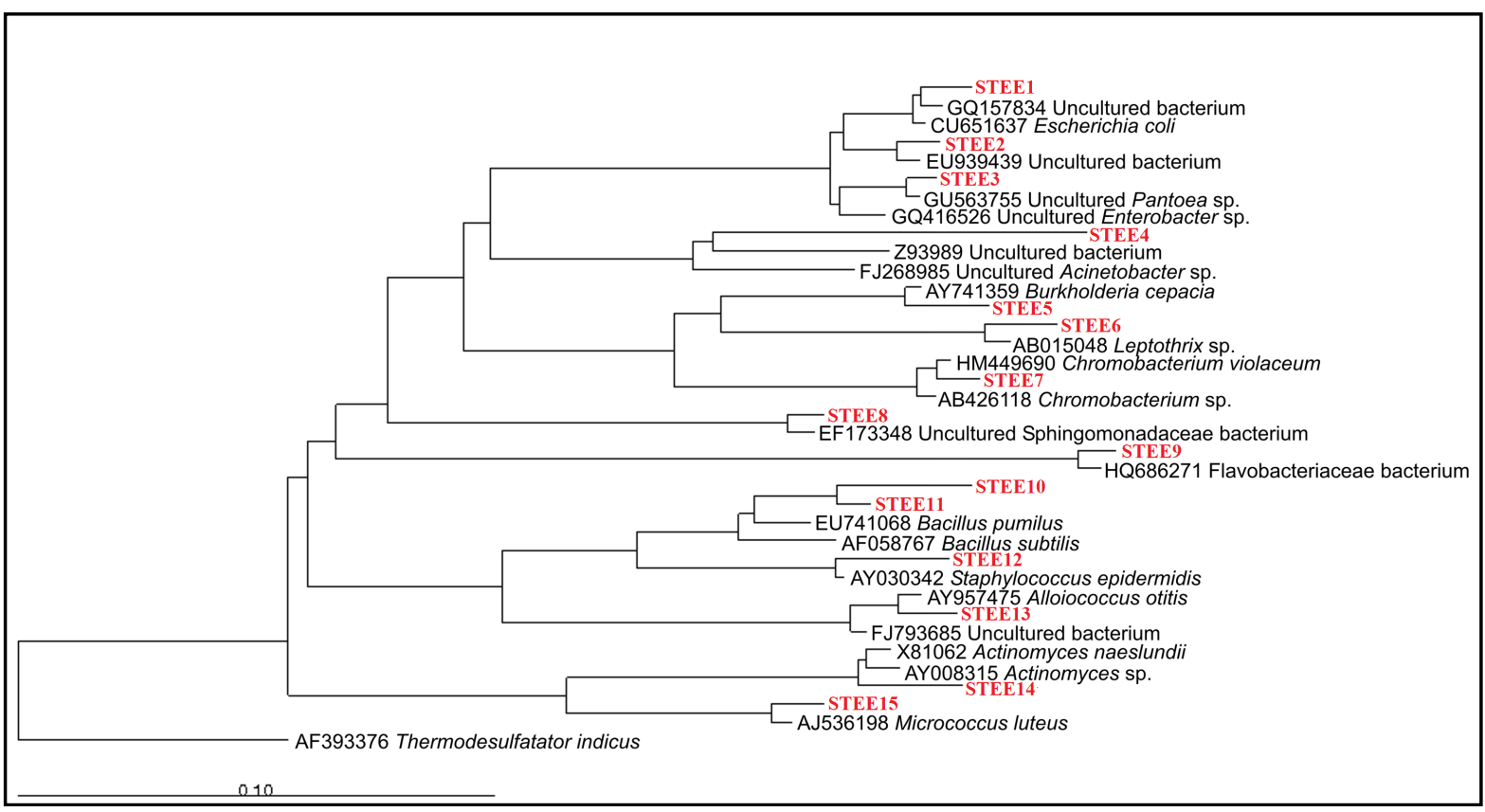

Resource 1. Phylogenetic neighbor-joining tree of bacterial OTUs from crude sludge from treatment of electroplating effluent (STEE) constructed using the ARB software.

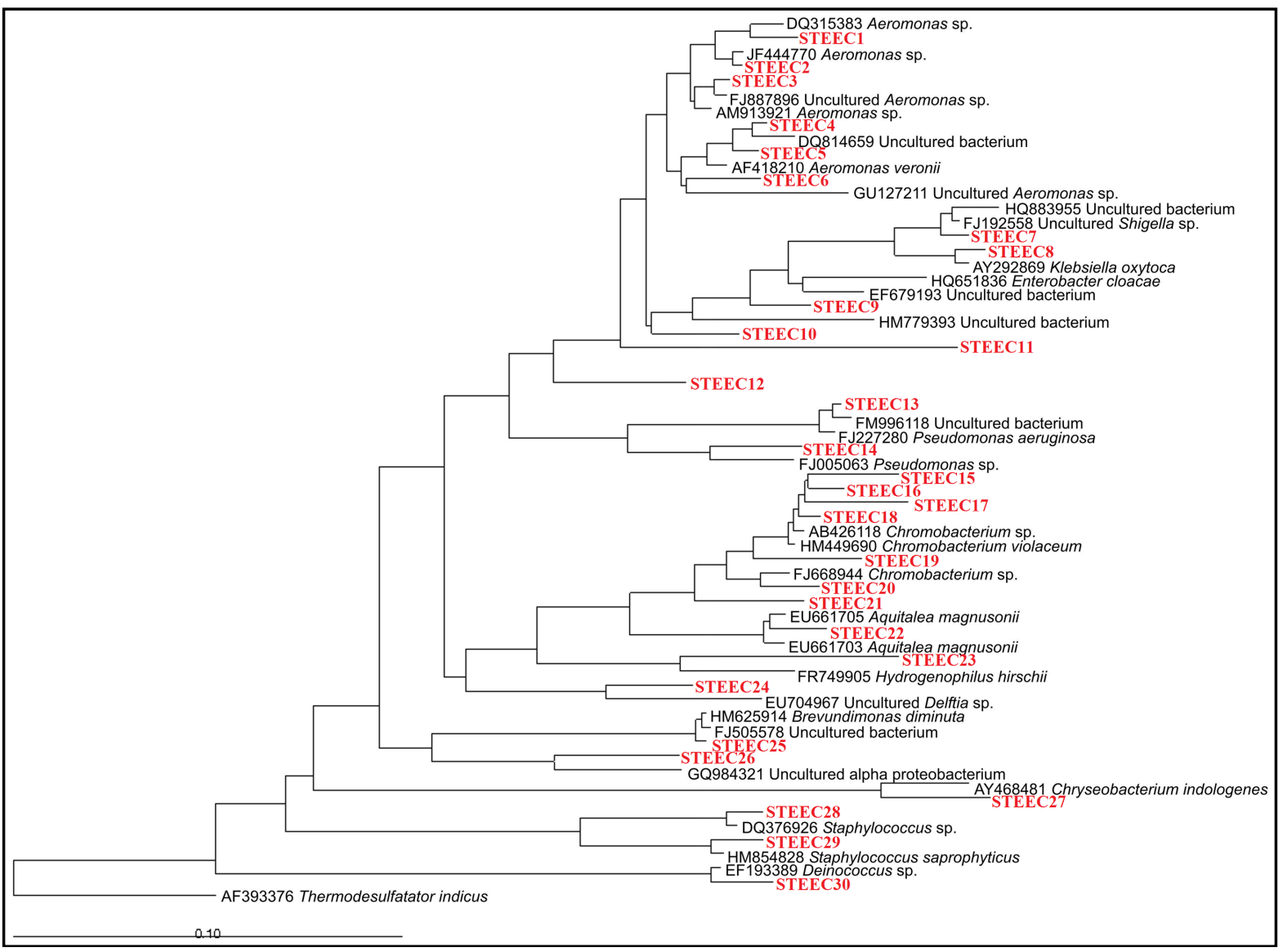

Resource 2. Phylogenetic neighbor-joining tree of bacterial OTUs from enrichment culture from treatment of electroplating effluent (STEEC) constructed using the ARB software. 


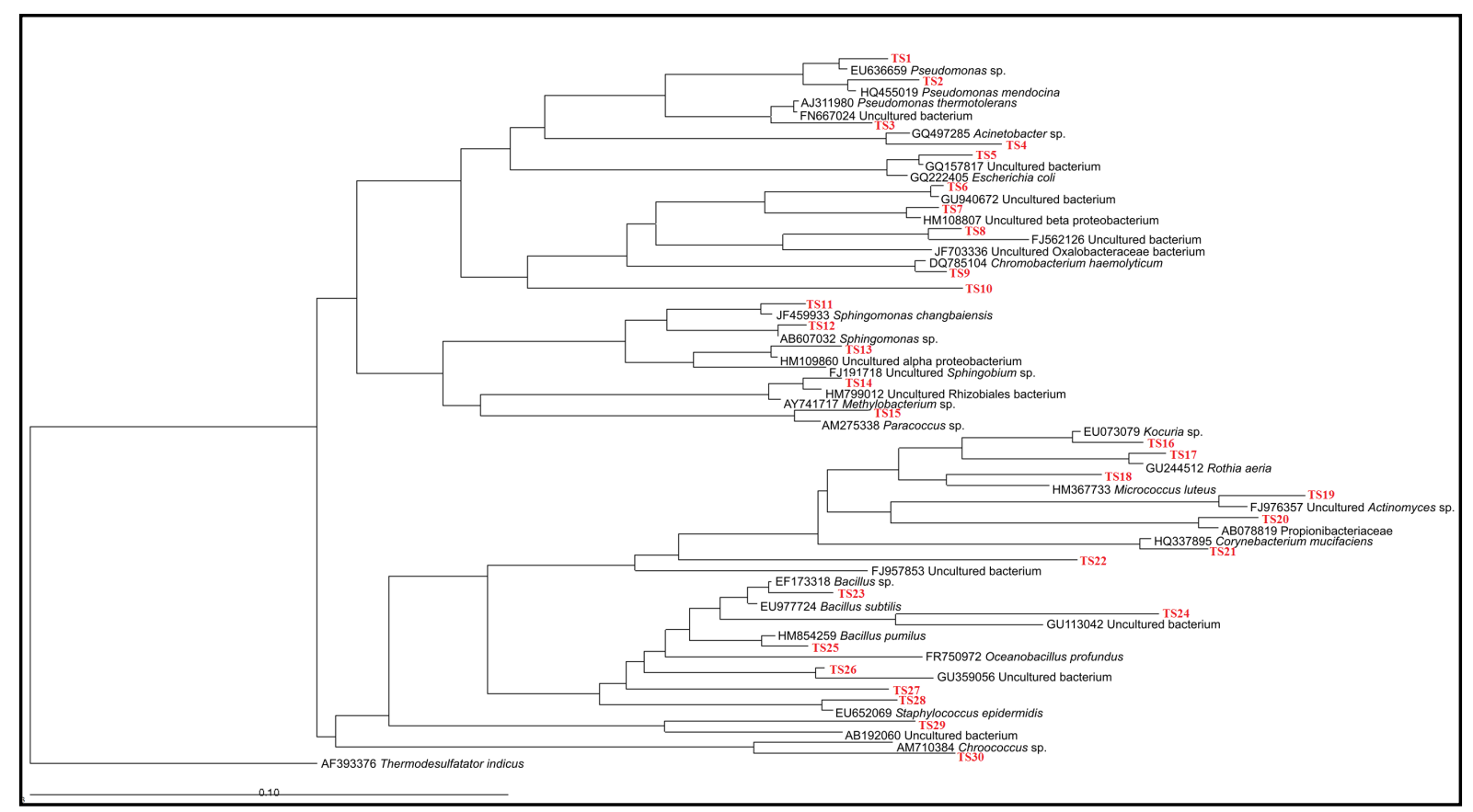

Resource 3. Phylogenetic neighbor-joining tree of bacterial OTUs from crude thin sludge (TS) constructed using the ARB software.

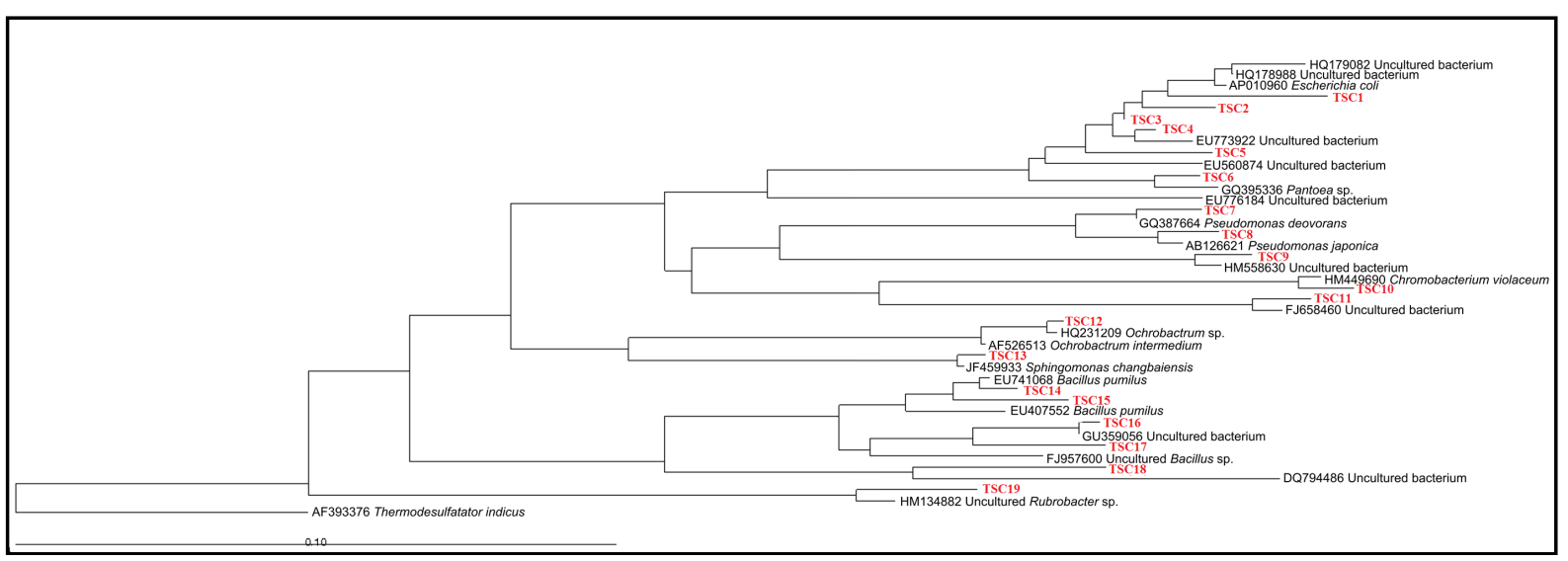

Resource 4. Phylogenetic neighbor-joining tree of bacterial OTUs from enrichment culture from thin sludge (TSC) constructed using the ARB software.

The Proteobacteria and Firmicutes phyla contained most of the OTUs identified in the crude STEE clone library (Figure 2(A)). Proteobacteria was represented by the Gammaproteobacteria (50\%), Betaproteobacteria (37\%), and Alphaproteobacteria (13\%) classes.

Clone library analysis from the STEEC revealed that the acidic $\mathrm{pH}$ promoted the emergence of Deinococcus-Thermus and disappearance of Actinobacteria (Figure 2(A) and Figure 2(B)). Overall, the 27 OTUs harbored two phyla in common with the STEE clone library: Proteobacteria and Firmicutes, with a strong dominance of Proteobacteria, represented by Gammaproteobacteria (54\%), Betaproteobateria (38\%), and Alphaproteobacteria (8\%) classes.

According to the phylogenetic analysis of the 16S rRNA gene sequences from the crude TS clone library, 30 OTUs were affiliated with the Proteobacteria, Firmicutes, Actinobacteria, and Cyanobacteria phyla (Figure 2(C)). Proteobacteria was the most abundant phylum, Firmicutes and Actinobacteria contributed evenly to bacterial community, whereas Cyanobacteria was present in lower ratios. Gammaproteobacteria (40\%), Alphaproteobacteria (33\%), and Betaproteobacteria (27\%) classes were found. 
The TSC clone library was composed of OTUs affiliated with Proteobacteria, Firmicutes, and Actinobacteria, with extensive variation in the proportional distributions of these phyla (Figure 2(D)). Gammaproteobacteria (70\%), Alphaproteobacteria (15\%), and Betaproteobacteria (15\%) classes were also present. Tables 1-4 show the classification of OTUs from all libraries down to genus and species level.

\subsection{Comparisons of Bacterial Compositions Based on OTU Clustering}

To determine the significance of differences between the clone libraries based on 16S rRNA gene sequences, we applied LIBSHUFF statistics, and the results revealed no significant differences in composition of bacterial communities.

To cluster sequences into OTUs and to distinguish between the shared and sample-specific OTUs, all sequence data were pooled together and analyzed using DOTUR (at $>97 \%$ similarity). The OTUs were divided into three categories as plotted in a Venn diagram (Figure 3): core OTUs shared by all crude and enriched samples, OTUs shared by two or three samples, and sample-specific OTUs. Four bacterial communities shared 11 OTUs comprising the Escherichia and Chromobacterium genera as shown in the diagram. The genus Ochrobactrum was present only in the enriched samples of both waste types (STEEC and TSC). The diagram also reveals that all crude and enriched samples shared four bacterial communities (Chromobacterium, Escherichia, Bacillus, and Ochrobactrum).

The potential role of these bacterial communities in the $\mathrm{Zn}$ extraction processes from steelmaking wastes will be discussed in the following section.

\section{Discussion}

Environmental metal pollution is a serious problem and the treatment or recovery of desired metals from wastes is a major challenge for the sustainable use of non-renewable natural resources such as $\mathrm{Zn}$. In this study, we performed assays under extremely acidic conditions, and showed that heterotrophic bacteria from steelmaking wastes were able to survive and had similar efficiency to extract $\mathrm{Zn}$ as in chemical leaching. However, the bioleaching assay could be considered more advantage since in this condition there was not need to addition acid

Table 1. Phylogenetic affiliation and distribution of bacterial 16S rRNA gene sequences analyzed from the STEE library.

\begin{tabular}{|c|c|c|c|c|}
\hline Phylogenetic group & Closest sequences/microorganism & Acession no. & Identity (\%) & Habitat of closest relative \\
\hline \multirow[t]{8}{*}{ Proteobacteria } & Escherichia sp. (3) & HМ028651 & $99.77 \%$ & Duck hatchery air \\
\hline & Enterobacter hormaechei (2) & FJ976588 & $97.32 \%$ & Paddy field soil \\
\hline & Pantoea sp. (3) & GU120653 & $99.26 \%$ & Mining waste land \\
\hline & Acinetobacter sp. (1) & EU100397 & $98.47 \%$ & Effluent of pesticides factories \\
\hline & Burkholderia sp. (1) & EF602552 & $93.19 \%$ & Sugarcane stem \\
\hline & Leptothrix sp. (2) & AB015048 & $97.90 \%$ & Halophilic spa \\
\hline & Chromobacterium sp. (13) & EF633687 & $98.94 \%$ & Spring water \\
\hline & Alterierythrobacter epoxidivorans (2) & DQ304436 & $97.86 \%$ & Marine sediments of cold seep area \\
\hline Bacteroidetes & Chryseobacterium sp. (2) & AM982789 & $97.69 \%$ & Homo sapiens \\
\hline \multirow[t]{4}{*}{ Firmicutes } & Bacillus sp. (12) & FN687186 & $99.67 \%$ & Feather waste \\
\hline & Bacillus sp. (2) & FJ615522 & $99.05 \%$ & Stratosphere \\
\hline & Staphylococcus subsp. aureus (1) & СР002120 & $99.03 \%$ & Bloodstream of a patient \\
\hline & Alloiococcus otitis (2) & AY957475 & $98.86 \%$ & 1 year old child with otitis perforata \\
\hline \multirow[t]{2}{*}{ Actinobacteria } & Actinomyces sp. (1) & AJ234049 & $98.39 \%$ & Canine and feline clinical specimens \\
\hline & Micrococcus luteus (1) & AJ717367 & $99.21 \%$ & Alkaline groundwater \\
\hline
\end{tabular}


Table 2. Phylogenetic affiliation and distribution of bacterial 16S rRNA gene sequences analyzed from the STEEC library.

\begin{tabular}{|c|c|c|c|c|}
\hline Phylogenetic group & Closest sequences/microorganism & Acession no. & Identity (\%) & Habitat of closest relative \\
\hline \multirow[t]{26}{*}{ Proteobacteria } & Aeromonas sp. (1) & DQ315383 & $97.93 \%$ & Silkworm \\
\hline & Aeromonas sp. (7) & FJ847841 & $99.62 \%$ & Snails (Helix aspersa) \\
\hline & Aeromonas sp. (1) & FN997620 & $96.61 \%$ & Estuarine sediment \\
\hline & Aeromonas sp. (4) & U88662 & $98.87 \%$ & Environmental sources \\
\hline & Aeromonas sp. (1) & U88662 & $95.89 \%$ & Environmental sources \\
\hline & Aeromonas sp. (1) & AB472911 & $95.71 \%$ & Ascites \\
\hline & Shigella sp. (1) & HM146924 & $99.62 \%$ & Rabbit intestine \\
\hline & Enterobacter sp. (2) & EU272859 & $99.81 \%$ & Cotton rhizosphere \\
\hline & Cedecea davisae (1) & AF493976 & $94.16 \%$ & Disinfecting footbaths \\
\hline & Aeromonas sp. (1) & AM913921 & $94.92 \%$ & Saccharina latissima \\
\hline & Aeromonas sp. (1) & EF111230 & $92.63 \%$ & Bogota river \\
\hline & Aeromonas sp. (1) & AF063003 & $91.15 \%$ & Water \\
\hline & Pseudomonas sp. (1) & FN663622 & $99.81 \%$ & Polluted pond water \\
\hline & Pseudomonas sp. (1) & AF320993 & $93.41 \%$ & Agaricus bisporus \\
\hline & Chromobacterium sp. (1) & EF633687 & $97.53 \%$ & Spring water \\
\hline & Chromobacterium sp. (1) & EF633687 & $98.12 \%$ & Spring water \\
\hline & Chromobacterium sp. (2) & EF633687 & $97.18 \%$ & Spring water \\
\hline & Chromobacterium sp. (27) & EF633687 & $99.44 \%$ & Spring water \\
\hline & Chromobacterium sp. (1) & EF633687 & $96.23 \%$ & Spring water \\
\hline & Chromobacterium sp. (2) & DQ985277 & $98.31 \%$ & Blackbird wetland soil \\
\hline & Chromobacterium sp. (1) & EF633687 & $96.24 \%$ & Spring water \\
\hline & Aquitalea sp. (1) & AB277847 & $97.74 \%$ & Denitrification reactors \\
\hline & Chromobacterium sp. (1) & EF633687 & $98.12 \%$ & Spring water \\
\hline & Delftia sp. (1) & AJ237966 & $91.15 \%$ & Industrial waste water \\
\hline & Brevundimonas diminuta (1) & EU977704 & $99.80 \%$ & Clean-room floor \\
\hline & Ochrobactrum sp. (1) & AB508888 & $98.21 \%$ & Rice paddy soil \\
\hline Deinococcus-Thermus & Deinococcus sp. (1) & EF193389 & $98.27 \%$ & Phyllosphere \\
\hline \multirow[t]{2}{*}{ Firmicutes } & Staphylococcus sp. (3) & FJ773995 & $99.44 \%$ & Soil \\
\hline & Bacillus sp. (1) & HM235923 & $99.45 \%$ & Tobacco cultivation soil \\
\hline Bacteroidetes & Chryseobacterium sp. (1) & AY464462 & $98.50 \%$ & Agricultural setting \\
\hline
\end{tabular}

to maintain the $\mathrm{pH}$ 2. The bioleaching process is often based on acidophilic bacteria such as Thiobacillus ferrooxidans, Leptospirillum ferrooxidans, and Acidithiobacillus thiooxidans, which have been implicated as being the most applicable bacteria involved in operation of biological metal-removal processes including Zn [18]-[20]. 
Table 3. Phylogenetic affiliation and distribution of bacterial 16S rRNA gene sequences analyzed from the TS library.

\begin{tabular}{|c|c|c|c|c|}
\hline $\begin{array}{l}\text { Phylogenetic } \\
\text { group }\end{array}$ & Closest sequences/microorganism & Acession no. & $\begin{array}{l}\text { Identity } \\
\text { (\%) }\end{array}$ & Habitat of closest relative \\
\hline \multirow[t]{15}{*}{ Proteobacteria } & Pseudomonas sp. (1) & DQ192044 & $99.05 \%$ & Asphalt seeps \\
\hline & Pseudomonas sp. (1) & DQ213044 & $98.50 \%$ & Yellow River estuary \\
\hline & Pseudomonas sp. (1) & EU162043 & $96.84 \%$ & Compost \\
\hline & Acinetobacter sp. (4) & HM489955 & $97.24 \%$ & Intestinal tract \\
\hline & Escherichia coli (2) & FJ823386 & $98.92 \%$ & Soil \\
\hline & Burkholderia sp. (8) & FJ603038 & $99.60 \%$ & Surface of weathered rock \\
\hline & Burkholderia cenocepacia (2) & EF602551 & $99.63 \%$ & Sugarcane stem \\
\hline & Massilia sp. (1) & AM237367 & $97.95 \%$ & Barnyard dust \\
\hline & Chromobacterium haemolyticum (4) & DQ785104 & $99.24 \%$ & Sputum culture \\
\hline & Stenotrophomonas maltophilia (1) & AJ293474 & $99.25 \%$ & Sewage \\
\hline & Sphingomonas sp. (1) & FJ455064 & $96.11 \%$ & Aerial part \\
\hline & Sphingomonas sp. (1) & AY749436 & $99.56 \%$ & Long term banking of genome resources \\
\hline & Sphingomonas sp. (1) & EU931555 & $98.25 \%$ & Sugarcane roots \\
\hline & Methylobacterium sp. (1) & AB252203 & $98.80 \%$ & Freshwater \\
\hline & Paracoccus sp. (1) & AM275338 & $97.37 \%$ & Deep sea sediment \\
\hline \multirow[t]{7}{*}{ Actinobacteria } & Kocuria sp. (1) & AY745813 & $98.09 \%$ & Eastern Chinese Sea \\
\hline & Rothia aeria (1) & EU293888 & $100 \%$ & Human infection \\
\hline & Micrococcus sp. (5) & AY745846 & $94.46 \%$ & Changjiang estuary \\
\hline & Actinomyces sp. (1) & AJ234049 & $97.68 \%$ & Canine and feline clinical specimens \\
\hline & Propiniobacterium acnes (2) & DQ672259 & $99.74 \%$ & Microdiscectomy \\
\hline & Corynebacterium sp. (1) & AF537600 & $98.55 \%$ & Blood \\
\hline & Corynebacterium sp. (1) & AF537593 & $87.99 \%$ & Blood culture \\
\hline \multirow[t]{7}{*}{ Firmicutes } & Bacillus sp. (9) & FJ465012 & $98.81 \%$ & Soil at $30-50$ m elevation \\
\hline & Bacillus sp. (1) & GU171355 & $95.42 \%$ & Soil from lawn \\
\hline & Bacillus sp. (6) & FN666893 & $99.51 \%$ & Landfill 3ft depth soil \\
\hline & Bacillus sp. (2) & HM566654 & $97.64 \%$ & Soil \\
\hline & Bacillus subtilis (1) & EU753871 & $93.09 \%$ & Lettuce \\
\hline & Staphylococcus sp. (1) & GU797281 & $98.79 \%$ & Dental caries \\
\hline & Turicibacter sp. (1) & NR_028816 & $85.76 \%$ & $\begin{array}{l}\text { Blood culture of a patient with } \\
\text { appendicitis }\end{array}$ \\
\hline Cyanobacteria & Chroococcus sp. (1) & AM710384 & $91.85 \%$ & Freshwater reservoir \\
\hline
\end{tabular}

In contrast to these reports we reveal herein heterotrophic bacteria phylogenetically distinct from acidophilic bacteria.

It is well-established that metals can be removed from a variety of wastes by lowering the $\mathrm{pH}$ either by the 
Table 4. Phylogenetic affiliation and distribution of bacterial 16S rRNA gene sequences analyzed from the TSC library.

\begin{tabular}{ccccc}
\hline Phylogenetic group & Closest sequences/microorganism & Acession no. & Identity (\%) & Habitat of closest relative \\
\hline Proteobacteria & Escherichia sp. (1) & GU594294 & $94.38 \%$ & Clinical samples \\
& Escherichia sp. (1) & HM576813 & $97.97 \%$ & Gastric ulcer swine \\
Escherichia sp. (51) & FJ405310 & $99.66 \%$ & Swine \\
Escherichia sp. (14) & AP010960 & $99.77 \%$ & Human infection \\
& Escherichia sp. (1) & DQ411026 & $96.19 \%$ & NOx removal system \\
Enterobacter sp. (1) & GQ451698 & $99.32 \%$ & High biodiversity regions of \\
Pseudomonas sp. (2) & AF326375 & $97.75 \%$ & Isolated from pulpmill effluent \\
& Pseudomonas japônica (1) & AB126621 & $98.93 \%$ & Activated sludge sample \\
Acinetobacter sp. (1) & GQ284532 & $98.22 \%$ & Mangrove sediment \\
Chromobacterium sp. (1) & EF633687 & $98.94 \%$ & Spring water \\
Alcaligenes faecalis (1) & AY959943 & $99.89 \%$ & Swine wastewater sludge \\
Ochrobactrum anthropi (1) & DQ647056 & $99.64 \%$ & Nodules of Cicer arietinum \\
Sphingomonas sp. (2) & EU682685 & $96.34 \%$ & Forest soil \\
Birmicutes & FJ615521 & $99.31 \%$ & Stratosphere \\
Bacillus sp. (1) & HM629506 & $95.94 \%$ & Mangrove sediment \\
Bacillus thuringiensis (1) & FJ462697 & $99.89 \%$ & Plant \\
Bacillus sp. (1) & EF032682 & $96.02 \%$ & Goat skin \\
Bacillus sp. (1) & FJ528074 & $91.69 \%$ & Farmland \\
Rubrobacter sp. (1) & FJ497714 & $98.30 \%$ & \\
\hline
\end{tabular}

* different OTUs

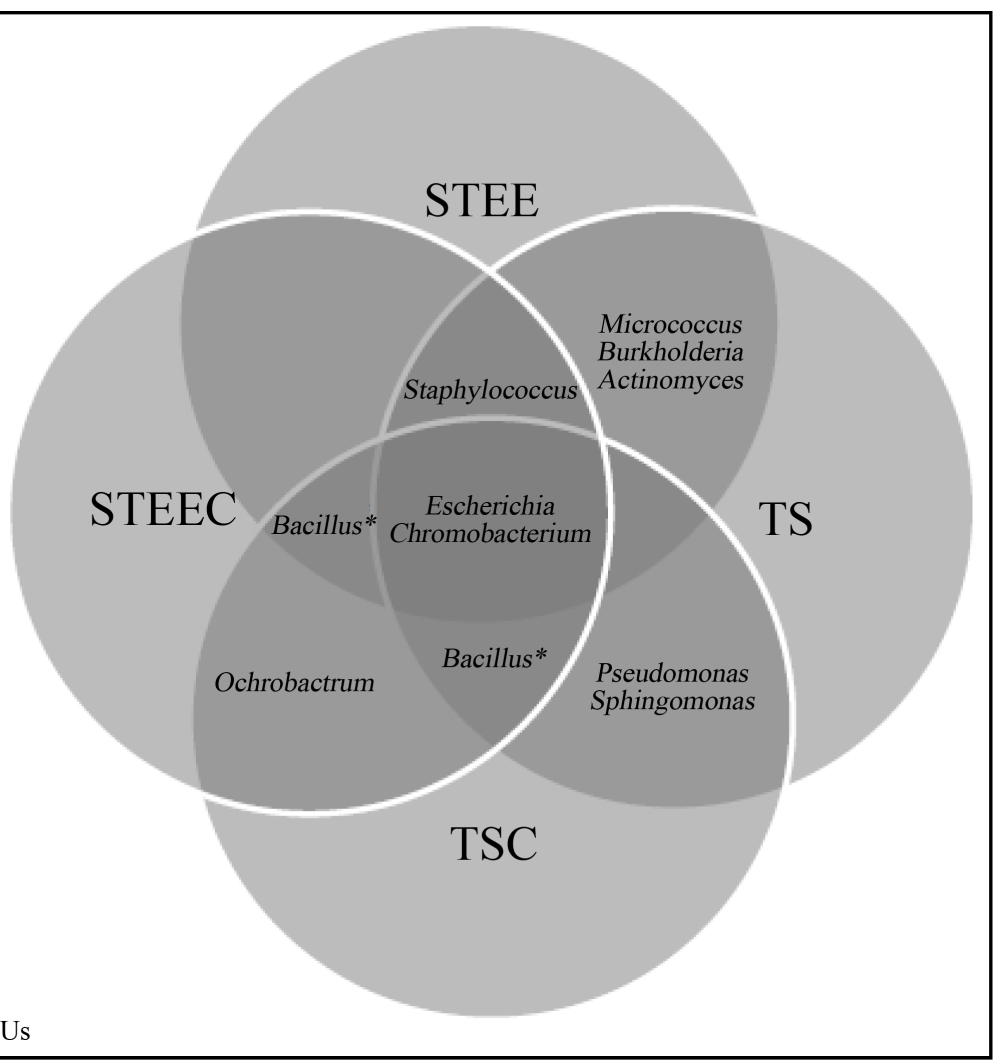

Figure 3. Comparative analysis of the OTU sequences shared among the four libraries. 
addition of acids or by the production of acids by bacterial activity. As expected, we found that a chemical $\mathrm{Zn}$ leaching process also occurred in our un-inoculated steelmaking waste samples.

The $\mathrm{pH}$ increase observed at the first seven days in both wastes, could be explained by consumption of $\mathrm{H}^{+}$ protons, which could be illustrated by the equation $\mathrm{Fe}^{2+}+0.5 \mathrm{O}_{2}+2 \mathrm{H}^{+} \rightarrow \mathrm{Fe}^{3+}+\mathrm{H}_{2} \mathrm{O}$ [21]. Even during this period, bacterial growth could occur through the energy obtained in the $\mathrm{Fe}^{2+}$ oxidation. The $\mathrm{Fe}^{3+}$ formed would be further used as in the equation $4 \mathrm{Fe}^{3+}+\mathrm{ZnS}+2 \mathrm{H}_{2} \mathrm{O}+\mathrm{O}_{2} \rightarrow \mathrm{Zn}^{2+}+4 \mathrm{Fe}^{2+}+\mathrm{SO}_{4}^{-2}+4 \mathrm{H}^{+}$, resulting in the release of protons and completing the iron redox cycling. Therefore, the combination of chemical reactions in acidic conditions, along with the emergence of bacterial metabolic activity favored the maintenance of a $\mathrm{pH}$ value of 2, at one week of leaching of the steelmaking samples analyzed. Thus, $\mathrm{pH}$ decrease in the bioleaching assays may be an indication of the bacterial activity enhancing the iron redox cycling and leading to an effective solubilization of Zn as suggested by Marhual et al. [22].

Using culture-independent molecular and enrichment culture approaches, this study provided insight into the bacteria from STEE, TS, STEEC, and TSC by revealing their phylogenetic identity. Overall, the steelmaking wastes harbored few lineages, suggesting an unfavorable environment for the bacterial communities present in them. Proteobacteria was systematically the phylum predominant (from $50 \%$ to $87 \%$ ) in all the clone libraries. According to Chen et al. [23], in a metal-rich environment the proteobacterial account for up to $70 \%$ of $16 \mathrm{~S}$ rRNA gene clone library sequences. Although the number of genera found was only eight, this ubiquitous phylum harbors several members associated with iron redox cycling and ability to leach metal in steelmaking wastes. Other phyla also disclosed herein have already been shown to harbor members with similar abilities [24]-[26].

Diverse bacterial taxa can be present in a metal-rich environment. However, metal-tolerant bacteria appear to be present as primary heterotrophic colonizers of exposed minerals [27]. Moreover, Johnson and Roberto [28] reported that heterotrophic bacteria can obtain carbon sources through the wastes products produced by the autotrophs and play a role in the mineral degradation processes. Given these data, it is likely that Zn leaching bacteria found in our steelmaking waste sample are also heterotrophic.

The Chromobacterium, Escherichia, Bacillus, and Ochrobactrum genera were common in the primary enrichment of both clone libraries, suggesting that they could play a role in Zn bioleaching of steelmaking wastes. Previous studies reported bioleaching ability of Chromobacterium violaceum to mobilize diverse metals, including Zn, from solid and electronic materials [29] [30]. An unexpected result was the occurrence of a strong dominance of Escherichia in the TSC waste. Indeed, it is not clear why and how this dominance occurs in such a poor carbon source environment and therefore further studies will be needed to clarify this matter. One possibility is the versatile behavior of $E$. coli which is able to tolerate and rapidly adapt to diverse stress environmental conditions such as low pH and strongly carbon-limited, among others (reviewed by [31]). Although Lin et al. [32] reported the ability of $E$. coli to survive at low $\mathrm{pH}$, it is the first time that this genus has been connected with $\mathrm{Zn}$ extraction and the first time it has been reported in steelmaking wastes.

Representatives of Bacillus have been reported to efficiently solubilize metals and thus contribute to metal leaching without any benefit to themselves [7] [33]. Only one other study found Bacillus from steelmaking waste sources. That work, which was from our laboratory, reported an interesting dominance of this genus in Blast Furnace Sludge wastes [34]. We also found members of Ochrobactrum in our steelmaking wastes. Ozdemir et al. [35] reported that members of this genus are involved in the solubilization of other metals such as chromium, cadmium, and copper. However, we did not find such metals in our samples, indicating the ability of Ochrobactrum to solubilize metals other than those.

Aeromonas was only found in the STEEC clone library, where it shared dominance with Chromobacterium. Indeed, a previous study showed the presence of Aeromonas in uranium deposits [36] while another study revealed that members of this genus were able to reduce $\mathrm{Fe}^{3+}$, nitrate, and sulfate [37].

This study is the first report of survival of heterotrophic bacteria from steelmaking wastes under extremely acidic conditions, such as Chromobacterium, Aeromonas, Escherichia, Bacillus, and Ochrobactrum. The data presented herein may be relevant for the management of this waste, particularly in the case of Zn extraction, making these bacteria candidates for future studies about metal bioleaching.

\section{Acknowledgements}

We thank FAPEMIG (Fundação de Amparo à Pesquisa do Estado de Minas Gerais), CAPES (Coordenação de Aperfeiçoamento de Pessoal de Nível Superior), and CNPq (Conselho Nacional de Desenvolvimento Científico 
e Tecnológico) for providing financial support. We also thank Usiminas, which provided the samples and the chemical characterization.

\section{References}

[1] Freitas, D.B., Reis, M.P., Freitas, L.M., Assis, P.S., Chartone-Souza, E. and Nascimento, A.M.A. (2008) Molecular Bacterial Diversity and Distribution in Waste from a Steel Plant. Canadian Journal of Microbiology, 54, 996-1005. http://dx.doi.org/10.1139/W08-094

[2] Tichy, R., Rulkens, W.H., Grotenhuis, J.T.C., Nydl, V., Cuypers, C. and Fajtl, J. (1998) Bioleaching of Metals from Soils or Sediments. Water Science and Technology, 37, 119-127. http://dx.doi.org/10.1016/S0273-1223(98)00242-X

[3] Xiang, L., Chan, L.C. and Wong, J.W.C. (2000) Removal of Heavy Metals from Anaerobically Degested Sewage Sludge by Isolated Indigenous Iron-Oxidizing Bacteria. Chemosphere, 41, $283-287$. http://dx.doi.org/10.1016/S0045-6535(99)00422-1

[4] Rohwerder, T., Gehrke, T., Kinzler, K. and Sand, W. (2003) Bioleaching Review, Part A: Progress in Bioleaching: Fundamentals and Mechanisms of Bacterial Metal Sulfide Oxidation. Applied Microbiology and Biotechnology, 63, 239-248. http://dx.doi.org/10.1007/s00253-003-1448-7

[5] Goebel, B.M. and Stackebrandt, E. (1994) Cultural and Phylogenetic Analysis of Mixed Microbial Populations Found in Natural and Commercial Bioleaching Environments. Applied and Environmental Microbiology, 60, 1614-1621.

[6] Makita, M., Esperon, M., Pereyra, B., Lopez, A. and Orrantia, E. (2004) Reduction of Arsenic Content in a Complex Galena Concentrate by Acidithiobacillus ferrooxidans. BMC Biotechnology, 4, 22. http://dx.doi.org/10.1186/1472-6750-4-22

[7] Bosecker, K. (1997) Bioleaching: Metal Solubilization by Microorganisms. FEMS Microbiology Reviews, 20, 591-604. http://dx.doi.org/10.1111/j.1574-6976.1997.tb00340.x

[8] Leathen, W.W., McIntyre, L.D. and Braley, S.A. (1951) A Medium for the Study of the Bacterial Oxidation of Ferrous Iron. Science, 114, 280-281. http://dx.doi.org/10.1126/science.114.2959.280

[9] Lane, D.J. (1991) 16S/23S rDNA Sequencing. In: Stackebrandt, E. and Goodfellow, M., Eds., Nucleic acid Techniques in Bacterial Systematic, Wiley, New York, 115-148.

[10] Erwing, B. and Grenn, P. (1998) Base-Calling of Automated Sequencer Traces Using Phred II. Error Probabilities. Genome Research, 8, 186-194.

[11] Green, P. (1994) PHRAP Documentation. http://www.phrap.org

[12] Gordon, D., Abajian, C. and Green, P. (1998) Consed: A Graphical Tool for Sequence Finishing. Genome Research, 8, 195-202. http://dx.doi.org/10.1101/gr.8.3.195

[13] DeSantis, T., Hugenholtz, P., Keller, K., Brodie, E., Larsen, N., Piceno, Y.M., Phan, R. and Andersen, G.L. (2006) NAST: A Multiple Sequence Alignment Server for Comparative Analysis of 16S rRNA Genes. Nucleic Acids Research, 34, W394-W399. http://dx.doi.org/10.1093/nar/gkl244

[14] Ludwig, W., Strunk, O., Westram, R., Richter, L., Meier, H., Buchner, A., et al. (2004) ARB: A Software Environment for Sequence Data. Nucleic Acids Research, 32, 1363-1371. http://dx.doi.org/10.1093/nar/gkh293

[15] Schloss, P.D. and Handelsman, J. (2005) Introducing DOTUR, a Computer Program for Defining Operational Taxonomic Units and Estimating Species Richness. Applied and Environmental Microbiology, 71, 1501-1506.

http://dx.doi.org/10.1128/AEM.71.3.1501-1506.2005

[16] Good, I.J. (1953) The Population Frequencies of Species and the Estimation of Population Parameters. Biometrika, 40, 237-264. http://dx.doi.org/10.1093/biomet/40.3-4.237

[17] Singleton, D.R., Furlong, M.A., Rathbun, S.L. and Whitman, W.B. (2001) Quantitative Comparisons of 16S rDNA Sequence Libraries from Environmental Samples. Applied and Environmental Microbiology, 67, 4373-4376. http://dx.doi.org/10.1128/AEM.67.9.4374-4376.2001

[18] Beolchini, F., Fonti, V., Ferella, F. and Vegliò, F. (2010) Metal Recovery from Spent Refinery Catalysts by Means of Biotechnological Strategies. Journal of Hazardous Materials, 178, 529-534.

http://dx.doi.org/10.1016/j.jhazmat.2010.01.114

[19] Hödar, C., Moreno, P., di Genova, A., Latorre, M., Reyes-Jara, A., Maass, A., González, M. and Cambiazo, V. (2012) Genome Wide Identification of Acidithiobacillus ferrooxidans (ATCC 23270) Transcription Factors and Comparative Analysis of ArsR and MerR Metal Regulators. Biometals, 25, 75-93. http://dx.doi.org/10.1007/s10534-011-9484-8

[20] Vukovic, M., Pesic, B., Strbac, N., Mihajlovic, I. and Sokic, M. (2012) Linear Polarization Study of the Corrosion of Iron in the Presence of Thiobacillus ferrooxidans Bacteria. International Journal of Electrochemical Science, 7, 24872503. 
[21] Xia, L., Dai, S., Chu, Y., Hu, Y., Liu, J. and Qiu, G. (2009) Comparison of Bioloeaching Behaviors of Different Compositional Sphalerite Using Leptospirillum ferriphilum, Acidithiobacillus ferrooxidans and Acidithiobacillus caldus. Journal of Industrial Microbiology \& Biotechnology, 36, 845-851. http://dx.doi.org/10.1007/s10295-009-0560-9

[22] Marhual, N.P., Pradhan, N., Kar, R.N., Sukla, L.B. and Mishra, B.K. (2008) Differential Bioleaching of Copper by Mesophilic and Moderately Thermophilic Acidophilic Consortium Enriched from Same Copper Mine Water Sample. Bioresource Technology, 99, 8331-8336. http://dx.doi.org/10.1016/j.biortech.2008.03.003

[23] Chen, Y.Q., Ren, G.J., An, S.Q., Sun, Q.Y., Liu, C.H. and Shuang, J.L. (2008) Changes in Bacterial Community Structure in Copper Mine Tailings after Colonisation of Reed (Phragmites communis). Pedosphere, 18, 731-740. http://dx.doi.org/10.1016/S1002-0160(08)60068-5

[24] Baker, B.J. and Banfield, J.F. (2003) Microbial Communities in Acid Mine Drainage. FEMS Microbiology Ecology, 44, 139-152. http://dx.doi.org/10.1016/S0168-6496(03)00028-X

[25] Hao, C.B., Zhang, H.X., Bai, Z.H., Hu, Q. and Zhang, B.G. (2007) A Novel Acidophile Community Populating Waste Ore Deposits at an Acid Mine Drainage. Journal of Environmental Sciences, 19, 444-450. http://dx.doi.org/10.1016/S1001-0742(07)60074-6

[26] Mendez, M.O., Neilson, J.W. and Maier, R.M. (2008) Characterization of a Bacterial Community in an Abandoned Semiarid Lead-Zinc Mine Tailing Site. Applied and Environmental Microbiology, 74, 3899-3907. http://dx.doi.org/10.1128/AEM.02883-07

[27] Freitas, D.B., Lima-Bittencourt, C.I., Reis, M.P., Costa, P.S., Assis, P.S., Chartone-Souza, E. and Nascimento, A.M.A. (2008) Molecular Characterization of Early Colonizer Bacteria from Wastes in a Steel Plant. Letters in Applied Microbiology, 47, 241-249. http://dx.doi.org/10.1111/j.1472-765X.2008.02415.x

[28] Johnson, D.B. and Roberto, F.F. (1997) Heterotrophic Acidophiles and Their Role in the Bioleaching of Sulfide Minerals. In: Rawlings, D.E., Ed., Biomining: Theory, Microbes and Industrial Processes, Springer-Velag, Berlin, 259-279. http://dx.doi.org/10.1007/978-3-662-06111-4_13

[29] Faramarzi, M.A., Stagars, M., Pensini, E., Krebs, W. and Brandl, H. (2004) Metal Solubilization from Metal-Containing Solid Materials by Cyanogenic Chromobacterium violaceum. Journal of Biotechnology, 113, 321-326. http://dx.doi.org/10.1016/j.jbiotec.2004.03.031

[30] Pradhan, J.K. and Kumar, S. (2012) Metals Bioleaching from Electronic Waste by Chromobacterium violaceum and Pseudomonas sp. Waste Management \& Research, 30, 1151-1159. http://dx.doi.org/10.1177/0734242X12437565

[31] van Elsas, J.D., Semenov, A.V., Costa, R. and Trevors, J.T. (2011) Survival of Escherichia coli in the Environment: Fundamental and Public Health Aspects. The ISME Journal, 5, 173-183. http://dx.doi.org/10.1038/ismej.2010.80

[32] Lin, J., Smith, M.P., Chapin, K.C., Baik, H.S., Bennett, G.N. and Foster, J.W. (1996) Mechanisms of Acid Resistance in Enterohemorrhagic Escherichia coli. Applied and Environmental Microbiology, 62, 3094-3100.

[33] Rawlings, D.E. (2005) Characteristics and Adaptability of Iron- and Sulfur-Oxidizing Microorganisms Used for the Recovery of Metals from Minerals and Their Concentrates. Microbial Cell Factories, 4, 13. http://dx.doi.org/10.1186/1475-2859-4-13

[34] Freitas, D.B., Reis, M.P., Lima-Bittencourt, C.I., Costa, P.S., Assis, P.S., Chartone-Souza, E. and Nascimento, A.M.A. (2008) Genotypic and Phenotypic Diversity of Bacillus spp. Isolated from Steel Plant Waste. BMC Research Notes, 1, 92. http://dx.doi.org/10.1186/1756-0500-1-92

[35] Ozdemir, G., Ozturk, T., Ceyhan, N., Isler, R. and Cosar, T. (2003) Heavy Metal Biosorption by Biomass of Ochrobactrum anthropi Producing Exopolysaccharide in Activated Sludge. Bioresource Technology, 90, 71-74. http://dx.doi.org/10.1016/S0960-8524(03)00088-9

[36] Chen, Z., Cheng, Y., Pan, D., Wu, Z., Li, B., Pan, X., Huang, Z., Lin, Z. and Guan, X. (2012) Diversity of Microbial Community in Shihongtan Sandstone-Type Uranium Deposits, Xinjiang, China. Geomicrobiology Journal, 29, 255263. http://dx.doi.org/10.1080/01490451.2011.598604

[37] Pham, C.A., Jung, S.J., Phung, N.T., Lee, J., Chang, I.S., Kim, B.H., Yi, H. and Chun, J. (2003) A Novel Electrochemically Active and Fe(III)-Reducing Bacterium Phylogenetically Related to Aeromonas hydrophila, Isolated from a Microbial Fuel Cell. FEMS Microbiology Letters, 223, 129-134. http://dx.doi.org/10.1016/S0378-1097(03)00354-9 
Scientific Research Publishing (SCIRP) is one of the largest Open Access journal publishers. It is currently publishing more than 200 open access, online, peer-reviewed journals covering a wide range of academic disciplines. SCIRP serves the worldwide academic communities and contributes to the progress and application of science with its publication.

Other selected journals from SCIRP are listed as below. Submit your manuscript to us via either submit@scirp.org or Online Submission Portal.
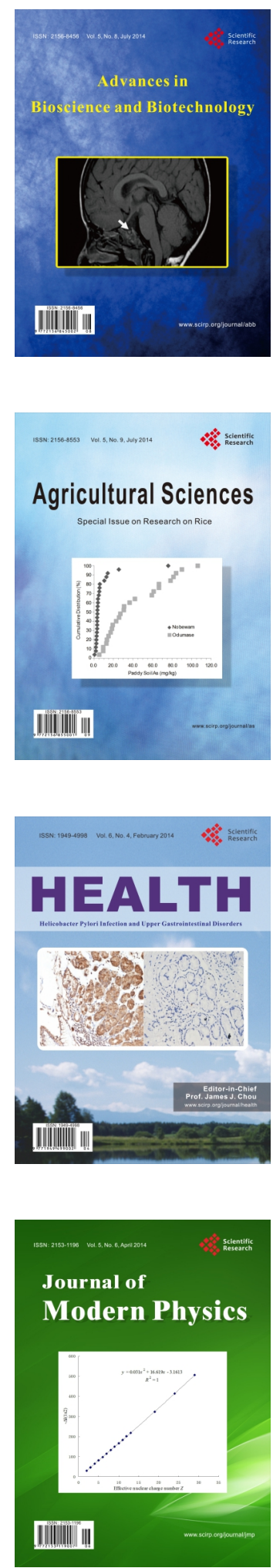
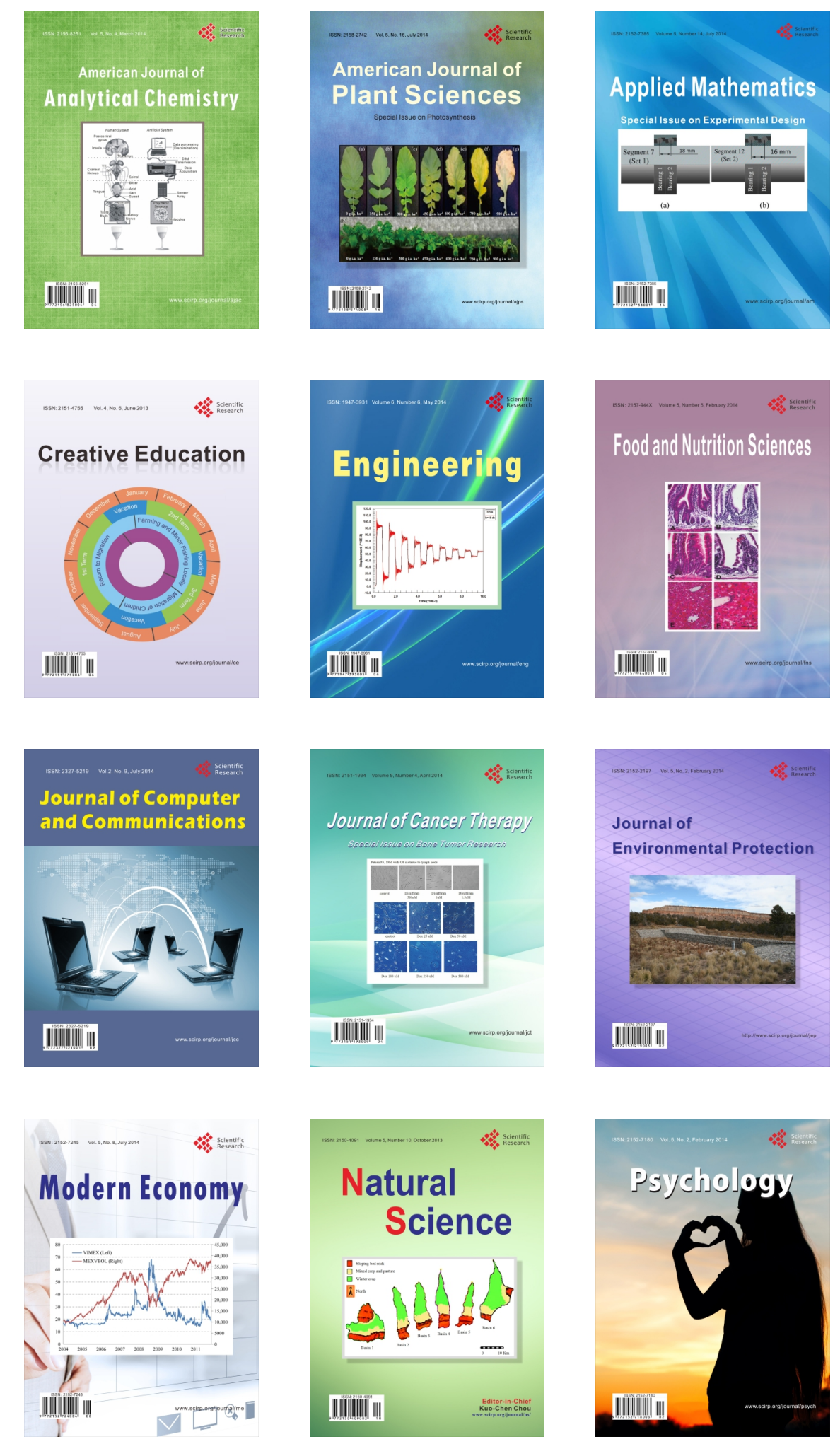